\title{
Exploring the Quality of Internet Banking Services in Kingdom of Bahrain
}

\author{
Ali Al-Soufi, Jaflah Al-Ammary, and Adel Al-Qallaf
}

\begin{abstract}
Revolutionary developments in marketing, information and communications technology continue to transform the banking and financial industry. Distribution of banking services through the Internet is an important part of this transformation. The objectives of this research were mainly to explore the quality of internet banking services in Bahrain. The study explored the customer's perceptions about internet banking and examined the quality of internet banking services in Bahrain. Moreover, this research addresses the key services provided by internet banking websites and compares those services according to bank actual services. In a way to achieve research objectives, an online survey has been done to explore the customers perceptions about internet banking while an instrument of nine dimensions are used to examine the quality of internet banking services on a sample of ten banks in Bahrain. Regard to exploring services provided by banks a comparison study applied on the same sample of ten banks. The findings show that the customers perceived the benefits and the risks of internet banking, all banks are applying most of the quality dimensions like: Reliability, Security, Privacy, Assurance, Trust, Efficiency, site aesthetics, and flexibility. While other quality dimensions are being weak like: Responsiveness and Access. All of internet banking websites is concentrating mainly on providing account information, transferring funds within the bank, and bill payments.
\end{abstract}

Index Terms-Quality internet banking, Bahrain online banking services.

\section{INTRODUCTION}

In the present days, internet consistently increases its importance as an effective communication channel providing unlimited, speedy and effective facilitation because of its geographic advantage and low cost. The vast majority of online users use the Internet to "conduct the everyday tasks and pursue the everyday pleasures of life, such as checking the weather, doing their banking, communicating with friends and family, and playing games" [1]. In the early period, most of financial institutions used a computer based systems to carry out all operations from simple to complex tasks. Nowadays Banking institutions have progressed a long way in the use of the internet, with most banks offering transaction services electronically over the internet. No longer are banks' web presences as heterogeneous as categorized in a study that identified three options in a company's web presence; ornamental, informational, or relational web presence (Jayawardhena, 2004) [2].

Manuscript received April 2, 2013; revised July 19, 2013.

A.AlSofi and J. Al-Ammary are with the Department of Information Systems, College of IT, University of Bahrain, Kingdom of Bahrain, (e-mail: \{ali.alsoufi, jalammari\}@ uob.edu.bh).

Adel AlQallaf is with the IT directorate of Ministry of Justice and Islamic Affairs, Kingdom of Bahrain (e-mail: algalaf@moia.gov.bh).
The internet brings huge opportunities for banking institutions, providing on-line services is becoming a strategic necessity for most of the banks which makes the Internet utilization an important and strategic distribution channel for providing banking services.

According to Mols [3], "there has been a considerable growth in the segment of consumers preferring Internet banking due to the increase in computer literacy, the availability of computers and the reduction in the costs of PCs and Internet access. This fact will change the optimal distribution structure for most banks and financial institutes". In this scenario, it is obvious that banks need to provide customers with a high quality of service - the quality of service is a key ingredient in the success of banks.

According to the Economist Intelligence Unit, Bahrain is the Gulf's banking hub. The Central Bank of Bahrain (CBB) licensed more than 40 retail-banks by end of 2010, [4]. Bahraini retail banks take the lead as internet banking takes off in the region. Recent statistics on the internet penetration levels in Bahrain stand at 77\% [5], of which Internet banking appears to be an important market. In light of these recent technological developments, this study explores the customer's perceptions about internet banking in Bahrain and result in to identify the level of quality of internet banking services in Bahrain. The investigation also includes an exploration of key services provided by internet banking websites in Bahrain and makes recommendations towards enhancing current internet banking quality and delivery.

The current study is aim to investigate the current situation regarding the internet banking in kingdom of Bahrain. To achieve the aim of the study the following objectives were set: investigate the different types of internet services provided, identify factors affecting the internet banking, investigate customer perception on the quality of the internet banking services provided, and examine the quality of the quality of the internet banking services.

\section{RESEARCH BACKGROUND}

\section{A. Retailer Bank}

Retail banking is essentially mass-market banking where individual customers use high-street branches of larger commercial banks. Retail banks offer services including savings and current accounts, mortgages, personal loans, debit cards, credit cards and so forth. Most retail banks are profit-making, private enterprises. The retail banking sector is one of the most competitive in the financial services sector.

Retail banking differs from wholesale banking, i.e. business to business banking, in that the transactions are between the customer and the bank as opposed to counterparties in wholesale banking. The relationship 
between the bank and the customer is usually referred to as "debtor and creditor", "principal and agent" or "mortgagor and mortgagee", depending on the services on offer by the bank to the customer.

Retail banks also offer services such as commercial lending to mid-market businesses, which is usually referred to as "business banking" as opposed to "personal banking" to individuals. Lending to organizations is an intensive activity, with banks carefully analyzing the financial condition of business clients to determine the level of risk in each loan transaction. A Retail bank is a bank that caters for ordinary individuals and small businesses, as distinct from large corporations. Retail banking operations offer deposit facilities, lend money, transfer funds and are prepared to deal in relatively small amounts."

\section{B. Bank Internet Services}

Information technology has been one of the driving forces in the changes that have occurred in trade and economy. Global trade is fifty times bigger today than 1950 and it continues to grow [6]. The Bahraini retail-banking sector is a fitting industry for exploration as it has seen large-scale adoption of self-service banking technologies (SSBTs) such as ATMs, Kiosks, SMS, telephone banking and Internet banking.

Internet Banking services are banking services delivered over the Internet. The services provided by banks over the Internet which once included only checking of accounts, have recently evolved to include a full range of banking services. It is not rare the case nowadays, when nearly all services accessible at the branch or by phone can be accessed on the Internet as well. The development of technology allows banks to offer not only "branch-based" services over the Internet, but also new added-value services which are available only online such as electronic commerce, real-time brokerage, financial information menus, e-mail alerts and third party services (tax payment, portals or management of electricity bills) (Centeno, 2003).[7]

Generally, customers' motivation to use internet banking services comes from a number of factors: freedom of time and space, speed, convenience, 24 hours a day availability and price incentives [8]. Despite all the advantages the Internet offers to both banks and their customers in terms of increased productivity and reduced costs, it also hides a lot of disadvantages and challenges for the service providers. On the Internet, the comparison between different service offerings is much easier and switching costs are lower, which makes it easier for customers to change service providers [9]. This, on its behalf, posts a challenge for the banks to not only acquire new customers, but retain their existing ones as well. To retain its customers, banks should try to make them satisfied with their services and offerings and this can be achieved through delivering high quality services. Delivering high quality online services requires understanding of the online service quality dimensions considered crucial and trying to improve the quality of the services provided over the Internet, so that a competitive advantage is gained.

\section{Internet Service Quality}

E-service quality is defined as overall customer assessment and judgment of e-service delivery in the virtual marketplace [9]. ]. Businesses that have been experienced and successful in offering e-services are starting to apprehend that besides website presence and low price, the important success or failure factors also include the electronic service quality [10], [11]. One of the reasons for the increase importance of e-services quality is that over the Internet, it is much easier for customers to compare different service offerings than through traditional channels [9]. Thus, customers of online services expect equal or higher levels of service quality than the customers of traditional services [9].

The importance of delivering high quality e-services has been recognized by many companies, but still there is the problem of how the quality of online services is defined, which its determinants are and how it can be actually measured. There exist many models and methods for measuring the quality of traditional services [12]-[15], but very few researches looked at quality of services delivered over the Internet [16].

\section{BANKING SYSTEM AND BANKING INTERNET SERVICES IN KINGDOM OF BAHRAIN}

The financial services sector has been a mainstay of the Bahrain economy and has been performing well over the past 5 years. At the end of 2010, the financial sector remained the largest contributor to Bahrain's economy, accounting for $26.6 \%$ of real GDP [4]. Bahrain banks are trying to strengthen their position in the market and improve their efficiency. Bahrain banks are demanding to find new distribution channels and methods of providing their services in order to maintain and increase their shares in the market. An attractive method of doing that is through the Internet because it can offer banking services at cheaper prices to more potential clients and the transactions can be carried out from anywhere in the world at any time. This means that by using Internet technology, financial institutions can establish a direct link to customers and improve their market shares while increasing their profits, without paying the high cost of building new branches. Bahrain is a thriving regional financial centre, as evidenced by the increasing number of institutions licensed and assets under management. The financial system includes a variety of institutions which provide products and services to both institutions and individuals. There were 416 banks and financial institutions operating in Bahrain in 2010 compared to 400 at end of 2009. The licensing framework for financial institutions operating in Bahrain has remained largely unchanged, with a variety of licenses granted to institutions in line with their principal activities [4]. The banking system in Bahrain consists of two types of banks, retail banks and wholesale banks, with each category including both conventional and Islamic licenses. Retail banks carry out retail and commercial banking activities whilst wholesale banks are oriented towards merchant and investment banking activities. Both license types operate in both $\mathrm{BD}$ and foreign currencies. Representative offices, investment business firms and ancillary service providers provide sundry services the round off the banking sector. Bahrain is one of the fastest growing telecommunications markets in the Gulf. According to the "Telecommunications Indicators Report" released by the [17], there was a $12.6 \%$ increase in industry revenue between 2009 and 2010. Figures also show that the telecommunications 
sector currently employs almost 2,400 workers, with Bahrainis constituting $87 \%$ of total employees. As of December 2010, TRA has issued 152 licenses to 68 companies. Out of these 68 companies, 16 operators currently provide telecommunications services. This growth in 2010 confirms the ongoing liberalization of the Bahrain telecommunications enterprises.

\section{Research Methodology and Data Collection}

In this research the authors will use a combination of the qualitative \& quantitative research methods (mixed Method Approach) as this help in overcoming certain disadvantages of each method. Three approaches were followed:

A survey consisted of 17 questions, categorized in 3 sections. The first section of the survey captured the demographic details such as age, gender, educational attainments, occupation and nationality. The second section of the survey captured the internet banking behavior while the last section captured the internet banking perceptions. The authors selected 5 dimensions of internet banking service quality to minimize the survey for the customers. The dimensions selected are usefulness, personalization, efficiency, cost, safety and privacy. This survey aims to identify the perceptions of customers about internet banking in Bahrain.

An evaluation of the quality of services of most ten famous commercial retail-banks in Bahrain is shown in Table I which the authors has real access on their internet banking websites. These ten websites are examined by authors' observation.

TABLE I: RETAIL BANKS HAVING INTERNET BANKING SYSTEMS

\begin{tabular}{lll}
\hline Bank name & Type & Banking system \\
\hline Ahli United Bank & International & Conventional \\
\hline Al Salam Bank-Bahrain & Local & Islamic \\
\hline Bahrain Islamic Bank & Local & Islamic \\
\hline Bank of Bahrain \& Kuwait & Local & Conventional \\
\hline BMI Bank & International & Conventional \\
\hline Khaleeji Commercial Bank & Local & Islamic \\
\hline HSBC Bahrain & International & Conventional \\
\hline National Bank of Bahrain & Local & Conventional \\
\hline Kuwait Finance House & International & Islamic \\
\hline Ithmaar Bank (Shamil Bank) & Local & Islamic \\
\hline
\end{tabular}

In order to develop an instrument for measuring the quality of online banking services, the authors will use as a basis the E-SQ instrument created by Zeithaml, Parasuraman and Malhotra in 2005 [18] for measuring quality of online services. However, the authors modified E-SQ scale to satisfy research objectives. The authors found 9 dimensions emerge as key to the delivery of optimum internet banking quality. These dimensions include:

Reliability: Correct technical functioning of the site and the accuracy of service promises, billing, and product information.

Responsiveness: Quick response and the ability to get help if there is a problem or question.

Access: Ability to get on the site quickly and to reach the company when needed.
Flexibility: Choice of ways to pay, ship, buy, search for, and return items.

Efficiency: Site is simple to use, structured properly, and requires a minimum of information to be input by the customer.

Assurance/ trust: Confidence the customer feels in dealing with the site and is due to the reputation of the site and the products or services it sells, as well as clear and truthful information presented.

Security/ privacy: Degree to which the customer believes the site is safe from intrusion and personal information is protected.

Site aesthetics: Appearance of the site.

TABLE II: MAIN SERVICES OF INTERNET BANKING WEBSITE

\begin{tabular}{|c|c|}
\hline Category & Service \\
\hline \multirow[t]{3}{*}{ Account information } & Account Summary \\
\hline & Account Statement \\
\hline & Transaction History \\
\hline \multirow[t]{5}{*}{ Transfer } & Within own accounts \\
\hline & Other accounts within Bank \\
\hline & Local Transfer \\
\hline & International Transfer \\
\hline & Transfer History \\
\hline \multirow[t]{4}{*}{ Credit Card } & Credit Card Summary \\
\hline & Credit Card Statement \\
\hline & Credit Card Payment \\
\hline & Transfer History \\
\hline Payments & Bill Payment/Inquiry \\
\hline \multirow[t]{10}{*}{ Instructions } & Open Investment Account \\
\hline & Request Demand Draft \\
\hline & Request Managers Cheque \\
\hline & Request Standing Orders \\
\hline & Request Cheque Book \\
\hline & Request ATM card \\
\hline & Open new Account request \\
\hline & Stop Cheque \\
\hline & Close account request \\
\hline & Instruction request history \\
\hline \multirow[t]{5}{*}{ Services } & Exchange Rates \\
\hline & Previous Month Profit Rate \\
\hline & Finance Application \\
\hline & Report Lost/Stolen Card \\
\hline & Cheque Status Inquiry \\
\hline \multirow[t]{5}{*}{ Preferences } & Update Profile \\
\hline & Change Password \\
\hline & My Preferences \\
\hline & Quick Links Setup \\
\hline & Account Preferences Setup \\
\hline \multirow[t]{3}{*}{ Messages } & Inbox \\
\hline & Sent \\
\hline & Compose \\
\hline SMS Notification & SMS Profile \\
\hline
\end{tabular}

Customization / personalization: How much and how easily the site can be tailored to individual customers' preferences, histories. The proposed nine dimensions of 
quality of internet Banking services mentioned above were also given weight depending on their importance.

- A comparison study between those ten banks according to their internet banking services. The authors will compare the services provided by internet banking websites from two angles: according to banking services listed in Table II and according to types of services [19] listed in Table III. This comparison to identify the key services provided by internet banking websites in Bahrain.

TABLE III: TYPES OF INTERNET BANKING SERVICES

\begin{tabular}{lll}
\hline $\begin{array}{l}\text { Internet } \\
\text { Banking Type }\end{array}$ & Weight & Description \\
\hline Informational & 1 & $\begin{array}{l}\text { Information about products and } \\
\text { services }\end{array}$ \\
\hline Communicative & 2 & $\begin{array}{l}\text { Emails, account enquiry, } \\
\text { applications }\end{array}$ \\
\hline Transactional & 3 & $\begin{array}{l}\text { Transferring funds, bill } \\
\text { payments }\end{array}$ \\
\hline
\end{tabular}

\section{Figures AND TABles Data ANALYSIS AND RESUlts}

This study focused on exploring the quality of internet banking services in Bahrain and giving recommendations towards enhancing current internet banking quality and delivery. From the analyzed data presented above, the finding highlighted as the following:

- More than half of respondents were using internet banking that means there is awareness about the importance of that service and that due to the well educated young generation as the authors found that most of the internet banking users are in the age of 25-34 and had university and high studies degree.

- Male respondents were more using internet banking than female that may due to most of females in Bahrain are unemployed.

- The people still had the fear from the safety and security on the internet and that was obvious in research results; more than $45 \%$ of the non internet banking users thought that internet banking is not safe.

- The banks are doing well in encouraging people through bank staff and advertisements because most of the internet banking users influenced by them.

- The customers who are using internet banking are very aware about the benefits of the internet banking. More than $64 \%$ assure that internet banking saved their time, $55 \%$ perceived the benefit of service availability all the time and wherever, and $42 \%$ believe that internet banking best in managing their finance.

- The customization and personalization are main dimensions encourages the people to use internet banking because it meet their needs and suit their lifestyle as research findings more than $60 \%$ of the respondents.

- The authors found that the efficiency of the internet banking website was the most important dimension outstanding to customer. The results was more $55 \%$ of the customer found that internet banking is simple to use and easy to manage their finance.

- Internet banking for most of the users was cost effective and better than going to bank and that due to cheap telecommunication and internet service.

- Most of internet banking users perceived the risk of this service and they found that it is safe and secure, but still there was a little fear of disclosing personal information on the internet.

The authors found that Reliability, Efficiency, assurance/trust and site aesthetics dimensions were central aspects in designing internet banking websites, Fig. 1. Security and privacy played a pivotal role in internet banking adoption and continued use, the authors found that all of internet banking websites were using secured mechanism for data transferring (SSL), except 1 case. In regard to the provision of internet banking flexibility, it was found to be significant, principally in the area of providing a wide range of banking services online, but the authors found that there are $30 \%$ of websites not providing option to choose preferred language.

\section{Overall Banks Evaluation}

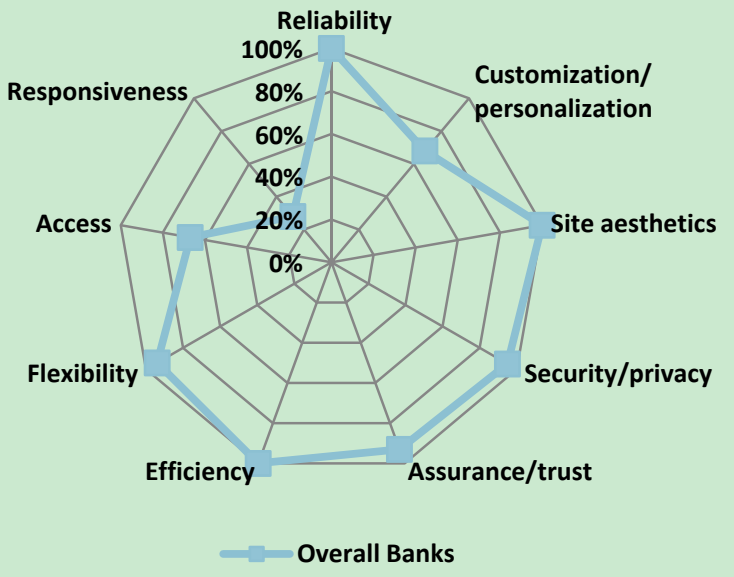

Fig. 1. Banks evaluation in quality of internet banking services.

Internet banking websites were notably lacking in the area of customer understanding. Most of the internet banking websites didn't provide an option to customize the preferences, quick links, and login landing option. Internet banking accessibility was perceived as important in terms of easy registration method, linkage from banks website to the internet banking website, and short URL which is easy to remember.

All banks websites have linkage to their internet banking websites but few of them provide online registration. The weakest dimension in internet banking in Bahrain was the responsiveness and that due to lack of relationship building through online customer service representative and online help with contact details provided. The authors found that the best internet banking websites that providing the biggest number of services were Ahli United Bank, Kuwait Finance House, and Bahrain Islamic Bank with 28 services equally for all, Fig. 2.

It was also identified that most of services provided by internet banking websites in Bahrain were of communicative type $(71 \%)$ and $25 \%$ are transactional services. Internet Banking websites are not informational but communicative and transactional websites. In contrast the Banks websites are 
extremely informational.

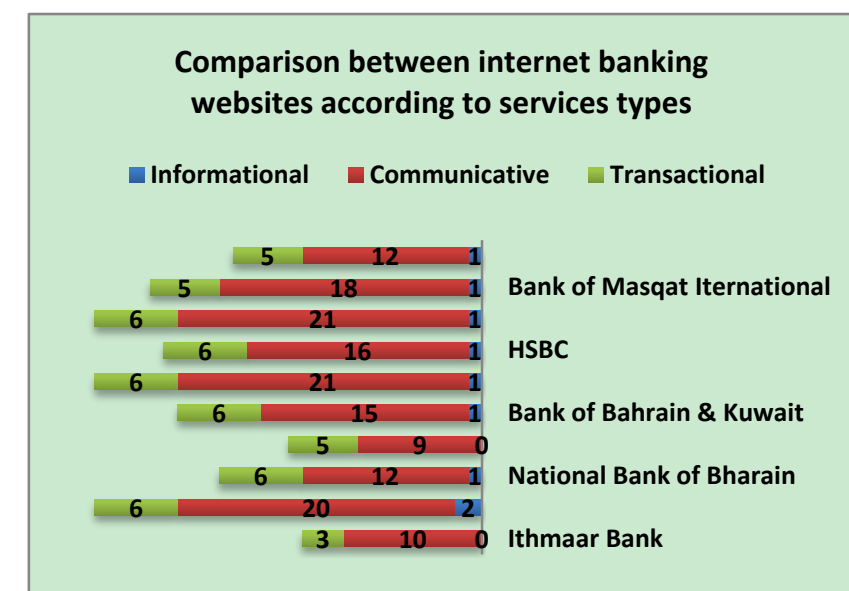

Fig. 2. Comparison between internet banking websites according to services types.

\section{DISCUSSION AND CONCLUSION}

In the following sections the study objectives will be discussed and answered. Furthermore the recommendations and suggestions for supplementary research will be presented.

\section{A. Answers for Research Questions}

What are the perceptions of customers about internet banking in Bahrain?

As it's obvious from the results and findings that internet banking becomes an important tool to customers to manage and monitor banking transactions. Half of the respondents using internet banking service and most of them are using internet banking for more than one year. The majority of internet banking users is influenced by banks advertisements, friends, and bank staff. As they realize the usefulness of internet banking in facilitating the management of banking transactions and realize the availability of this service all the time and everywhere. Most of internet banking users believed that this service is time and cost effective, safe and secure Respondents were not using internet banking mainly because they feel it's not safe and difficult while some of them feel no need for it.

To what extent are banks applying the service qualities in providing internet banking service?

In regard to internet banking quality of service the authors found that all banks that were examined in this study were applying most of the quality dimensions like: Reliability, Security, Privacy, Assurance, Trust, Efficiency, site aesthetics, and flexibility. While some of quality dimensions were being weak and ignored like: Responsiveness and Access. The authors found that National Bank of Bahrain was the best applier for these quality dimensions and followed by Ahli United Bank and Khaleeji Commercial Bank.

What are the Key services provided by each internet banking websites in Bahrain?

All of internet banking websites concentrated on providing account information, transferring funds within the bank, and bill payments. The majority provided credit card information, standing order, and cheques book requests.
To conclude, the potential for internet banking is present for all banks to utilize. This research has explored the quality of internet banking in Bahrain and discovering the customer perceptions about this service. The banks that stand to gain full advantage of internet banking are the ones who have done their marketing and demographic research and who are able to attract their targeted group by devising interesting and memorable homepages to benefit from the increase in internet banking services.

\section{B. Recommendations}

This study has raised number of recommendations towards enhancing current internet banking quality and delivery in Bahrain, and they are summarized as follows:

- The banks must restudy their internet banking websites and redesign it according to standards of quality of online services to provide the optimum quality of service to customers.

- Banks should increase customer loyalty and cross selling by targeting smaller and smaller groups until ultimately the banks offer tailored products for individual customers.

- Banks must do more in customer awareness about internet banking to decrease the fear of safety on the internet and create a need to this service.

- Banks must participate strategically in enhancing the education in the country because there is a solid relation between the education level and using internet banking.

- Central Bank of Bahrain (CBB) must work more in building standards of quality of internet banking services and standardize the services that should be provided in internet banking website and all that should be based on deep researches and studies.

\section{REFERENCES}

[1] D. D. Fallows, "Many Americans use the Internet in everyday activities, but traditional offline habits still dominate," Pew Internet \& American Life Project, 2004, pp. 40.

[2] C. Jayawardhena, "Measurement of service quality in internet banking: the development of an instrument," Journal of Marketing Management, vol. 20, pp. 185-207, 2004

[3] N. Mols, "The internet and banks' strategic distribution channel decisions," International Journal of Bank Marketing, vol. 17, no. 6, pp 295-300, 2002.

[4] CBB. (2007). Economic Report 2007. Central Bank of Bahrain. [Online]. Available: http://www.cbb.gov.bh

[5] Internet World Stats. (2012). [Online]. Available: http://www.internetworldstats.com/middle.htm\#bh

[6] E. Andersson, Globaliseringens politiska ekonomi- en introduktion, Studentlitteratur, Lund, 2001.

[7] C. Centeno, Adoption of internet services in the enlarged European Union: lessons from the internet banking case, European commission joint research centre, Report EUR 20822 EN, June, 2003.

[8] M. Mattila, H. Karjaluoto, and T. Pento, Internet adoption factors in Finland, 2002, University of Lyvaeskyla.

[9] J. Santos, "E-service quality: a model of virtual service quality dimensions," Managing Service Quality, vol. 13, no. 3, pp. 233-246 2003.

[10] Z. Yang, "Customer perceptions of service quality in internet-based electronic commerce," in Proc. the 30th EMAC Conference, Bergen, 2001, pp. 8-11.

[11] V. Zeithaml, "Service excellent in electronic channels," Managing Service Quality, vol. 12, no. 3, pp.135-138, 2002.

[12] A. Cowling and K, Newman, K., "Banking on people: TQM, service quality, and human resources", Personnel Review, vol. 24, no. 7, pp. 25-40, 1995.

[13] R. Johnston, "The determinants of service quality: satisfiers and dissatisfiers," International Journal of Service Industry Management, vol. 6, no. 5, pp. 53-71, 1995. 
[14] K. Bahia and J. Nantel, "A reliable and valid measurement scale for the perceived service quality of banks," International Journal of Bank Marketing, vol. 18, no. 2, pp. 84-91, 2000.

[15] H. Oppewal and M. Vriens, "Measuring perceived service quality using integrated conjoint experiments," International Journal of Bank Marketing, vol. 18, no. 4, pp. 154-169, 2000.

[16] J. Cox and B. Dale, "Service quality and e-commerce: an exploratory analysis," Managing Service Quality, vol. 11, no. 2, pp. 121-131, 2001

[17] TRA. (2010). TRA Annual Report. [Online]. Available: http:// www.tra.org.bh

[18] A. Parasuraman, V. Zeithaml, and A. Malhotra, "E-S-QUAL: A multiple-item scale for assessing electronic service quality," Journal of Service Research, vol.7, no. 3, pp. 213-233, 2005

[19] Comptroller of the Currency Administrator of National Banks, Internet Banking Comptroller's Handbook, 1999.

Ali AlSoufi has earned his PhD in computer science in 1994 from Nottingham University, UK. He has 23 years of experience in IT field, both in Academia and Industry. He has worked for Bahrain Telecom Co for 8 years as a Senior Manager Application Programme where he overlooked number of mega IS Application projects. Between 2007-2010; Dr Ali worked at Arab Open University as the head of IT and Computing program and Assistant Director for Business Development. He is also working as a consultant for Bahrain e-Government Authority (EGA) in the area of Enterprise Architecture. He is currently a member of the EGA's strategy II team for the kingdom of Bahrain. Ali is also an active member of the Bahrain National ICT Governance Committee. Dr Ali is now working for University of Bahrain as assistant Professor. He has number of publications in various fields of Information Technology, and has regular contributions in both academic and industrial IT activities.

Jaflah Hassan Al-Ammary is the head of the Department of Information Systems in the College of IT at the University of Bahrain. Al-Ammary holds a B.S in computer science from the University of Bahrain, M.Sc. from the Arabian Gulf University, and $\mathrm{PhD}$ from the University of Murdoch (Australia). Al-Ammary's research interest focuses on Strategic alignment, Knowledge Management, and educational technology and e-learning. Al-Ammary has many publications on KM-strategic alignment and the strategic role of the Information systems and SISP at the organization of Bahrain. On the other hand, she has conducted number of researches to examine the importance of the educational technology (such as blackboard, and Online Collaboration Learning) on enhancing the learning and teaching process and the emergent roles of professional learning community in developing the teachers' teaching capabilities and responsibility toward students in the secondary school of the Kingdom of Bahrain. Most of these researches have been published in international conferences and journals.

Adel AlQallaf is the chief of Information Technology Department in Ministry of Justice and Islamic Affairs. AlQallaf holds a B.S in computer science from the University of Bahrain, Master in Business Administration from Open University of Malaysia. He has 9 years of IT experience including 5 years of management experience. 